\title{
Identifying and treating subclinical thyroid dysfunction in pregnancy: emerging controversies
}

\author{
Inés Velasco ${ }^{1}$ and Peter Taylor ${ }^{2}$ \\ ${ }^{1}$ Pediatrics, Gynecology \& Obstetrics Unit, Riotinto Hospital, Huelva, Spain and ${ }^{2}$ Thyroid Research Group, Systems \\ Immunity Research Institute, Cardiff University School of Medicine, Cardiff, UK
}

Correspondence should be addressed to I Velasco Email:

inesvelas@msn.com

\begin{abstract}
Thyroid hormones are essential for an adequate growth and development of the fetus. In addition to the classical association between maternal hypothyroidism and neurological impairment in the progeny, other adverse reproductive events have been associated with maternal thyroid dysfunction including infertility, miscarriage and preterm delivery. Although all scientific societies endorse the treatment of overt hypothyroidism; the management and/or treatment of subclinical hypothyroidism, hypothyroxinemia or antithyroid antibody-positive women should be considered with caution. Important trials have found no clear benefit of treatment of subclinical hypothyroidism in terms of cognitive outcomes; however, other interventional studies appear to reduce some of the obstetric and perinatal complications. As a result, the dilemma between universal screening or selective screening of women at high risk of thyroid dysfunction during pregnancy remains unresolved. Despite this, levothyroxine is also now regularly prescribed by gynaecologists and centres for reproductive medicine. In this context, there is increasing concern regarding the risk of over diagnosis and subsequent potential overtreatment. Taken together, we need to reconsider how thyroid dysfunction should be identified in pregnant women and highlight the arguments for and against the use of levothyroxine in obstetric practices. Our main findings: the mismatch between the guidelines recommendations and the use of LT4 in clinical settings as well as the disparity of criteria between scientific societies from different medical specialties. In conclusion, it is essential to reach agreements between both endocrinologists and obstetricians.
\end{abstract}

\section{Introduction}

Over the last two decades, we have witnessed a revolution in our knowledge of the role of thyroid hormones in intrauterine stages of development (1). However, important uncertainties remain regarding both the screening and management of maternal thyroid status in optimising perinatal outcomes $(2,3)$.

Different clinical guidelines have been published by scientific societies in a relatively short period of time $(4,5,6,7)$, trying to shed light on the most burning questions whilst two important trials were carried out $(8,9)$. However, the absence of clear evidence of the

www.eje-online.org https://doi.org/10.1530/EJE-17-0598
(C) 2018 European Society of Endocrinology Printed in Great Britain effectiveness of treatment of subclinical hypothyroidism on child cognition, contrasts with promising results for other reproductive outcomes such as preterm delivery (10) or miscarriage $(11,12)$.

But the striking paradox is that whilst the scientists search for stronger evidence, clinicians are increasingly using levothyroxine empirically $(13,14)$.

Our aim has therefore been to summarise complementary and sometimes contradictory viewpoints around the assessment of thyroid function during pregnancy and the subsequent management of thyroid disease. 


\section{Reasons for universal screening}

Universal screening for thyroid function at early stages of gestation has become a recurrent controversy in the scientific literature $(2,15)$ and has even generated interest in the general population (16). In spite of the fact that scientific societies do not recommend this clinical approach during pregnancy at present, the most recent clinical guidelines address how to interpret and manage thyroid diseases that might have only been identified by effective universal screening $(4,5,6,7)$.

In 2014, we published the arguments for universal screening (15) following the criteria established by Beaglehole (17): Is thyroid dysfunction during pregnancy really a health problem? Are simple and reliable diagnostic tests available? Is universal screening cost-effective? Is there a simple, safe and economically affordable treatment? And how and when should all of this occur?

\section{Box 1: Criteria for screening by Wilson and Junger (18)}

1. Is it an important health problem?

2. Is there an accepted treatment?

3. Are facilities for diagnosis and treatment available?

4. Is there should a recognizable latent stage where symptoms are lacking?

5. Is there should a suitable test or examination?

6. Is the test acceptable to the general population?

7. Is the natural history of the condition, including development from latent to declared disease understood?

8. Is there an agreed policy on whom to treat as patients?

9. Is the cost of case finding (including diagnosis and treatment of patients diagnosed) economically appropriate?

10. Case finding should be a continuing process and not a 'once and for all' project.

This should be considered as the 10 key criteria for screening set out by Wilson and Junger (18).

Careful analysis of these 10 criteria provides a persuasive case for universal thyroid screening in pregnancy. For criteria 1, it is well established that thyroid dysfunction, particularly overt thyroid disease in pregnancy is an important health problem. Treatment of both hypothyroidism and hyperthyroidism result in improved outcomes with treatment and testing being both acceptable and widely available (criteria 2, 3, 5 and 6). For hypothyroidism in particular, there is a well-recognised latent asymptomatic stage (criteria 4 and 7). The cost of universal thyroid screening is favourable even if only the overt disease is considered (19); furthermore, the nature of screening in pregnancy ensures that it will be a continuous process (criterion 10). However, universal thyroid screening struggles to meet criterion 8 as a policy on whom to treat is yet to be agreed. Whilst all societies would recommend treatment of overt thyroid disease, there is much greater debate as to whether subclinical hypothyroidism and isolated hypothyroxinemia should be treated.

We will now study these arguments in more detail. The reasons for the implementation of a systematic determination of thyroid hormones at the first trimester of pregnancy might also be classified according to the purpose of the detection itself.

- For Endocrinology, the most obvious argument is the association of maternal overt hypothyroidism with obstetric and perinatal complications and the clinical impact of its early detection and treatment (20). Additionally, universal screening has shown to be more effective to detect all cases of thyroid dysfunction than targeted high-risk case-finding approach $(21,22)$. High-risk screening will miss the majority of cases.

- For Epidemiology, the relatively high prevalence of thyroid diseases in women (particularly at childbearing age) and their likelihood to be present in cases of infertility, recurrent miscarriages and other adverse events in obstetrical settings (23).

- For Medical Research in general, more and more investigation is currently focussed on the first '1000 days' from pregnancy until two years of life as a crucial stage in Epigenetics (24). In this regard, thyroid hormones play a pivotal role in metabolic regulation and neurodevelopment (25).

- For Health Economics, several studies have shown that the universal analysis of thyroid function is costeffective in comparison with the study of targeted groups of pregnant women $(19,26)$.

- For Public Health, because pregnancy is considered a privileged condition for preventive actions and a window to address some health conditions lifelong (27).

More recently, new factors have emerged that should be regarded:

1. The effectiveness of levothyroxine to ameliorate clinical pregnancy outcomes in women with subclinical hypothyroidism and/or thyroid autoimmunity undergoing assisted reproduction techniques (ART) and the dissemination of these results in reproductive medicine journals (28) has 
led to the strict preconceptional adjustment of TSH levels in infertile women attempting conception (29). Levothyroxine therapy is becoming widespread among women undergoing in vitro fertilization even in euthyroid patients (30).

2. The acceptance of a thyroid-stimulating hormone (TSH) level of $2.5 \mathrm{U} / \mathrm{L}$ as the upper limit of normal of TSH at first trimester has resulted in a substantial increase in the number of women being classified as hypothyroid in different populations $(31,32)$. In fact, one of the most relevant changes from the 2011 guidelines of the American Thyroid Association (ATA) (33) to the 2017 guidelines (7) is that in the absence of specific population-based reference ranges, the upper reference limit of $4.0 \mathrm{U} / \mathrm{L}$ may be used instead of the previously recommended limit of $2.5 \mathrm{U} / \mathrm{L}$ for TSH. However, those clinicians who have been using the former cut-off over the last five or six years will need time to change their practice.

3. Some concern has been raised that overtreatment with levothyroxine might have a deleterious effect on neurological development (34).

These circumstances have created a new scenario where many pregnant women are receiving levothyroxine therapy in cases of mild thyroid dysfunction or in the absence of population-based trimester-specific reference ranges. Probably, it is time to think that a sensible approach to reduce the potential harmful effect of unnecessary or questionable treatments might be to implement responsible strategies of universal screening for thyroid diseases within the pregnancy surveillance programmes, promoting pluridisciplinary endocrinological/obstetrical approaches.

Even within those who endorse universal screening, it is not clear which test should be used and when to perform screening. The current guidelines recommend a single TSH test with reflex TPOAb if TSH is between 2.5 and $10 \mathrm{U} / \mathrm{L}$, even though the elapsed time before the TPOAb determination might delay any intervention. This is particularly crucial as the first 12 weeks are critical for optimising neurological development.

If a possible therapy with levothyroxine could improve pregnancy outcomes, it should be started as soon as possible (or better still before conception), which reinforces the necessity to screen at least early in the first trimester, around 9-11 weeks of amenorrhea coinciding with a blood test in the first trimester. Furthermore, the combination of screening for thyroid dysfunction and aneuploidies would substantially improve the acceptability, simplicity, ease of administration and cost of this approach.

\section{Reasons against universal screening}

An adequate assessment of thyroid function in pregnant women requires specific practicalities that cannot be underestimated (35).

First of all, the dynamic changes in thyroid function throughout gestation (32) and its complex relationship with human chorionic gonadotrophin (hCG) (36) results in gestational age as a key determining factor in interpreting the thyroid function tests correctly. Although the use of trimester-specific reference range is strongly recommended (7), they are not currently available in many centres or they are not based on local populations (37). Although this would rapidly change if universal screening was introduced.

This dynamic change in thyroid physiology is more relevant in the early stages of gestation and, consequently, TSH reference limits differ widely within the first trimester of pregnancy (38). Whilst the lower TSH in weeks 9-12 of pregnancy are evidently explained by the high hCG production, considerably higher TSH values were observed earlier than 6 weeks of gestation, which are similar to non-pregnancy reference limits. The use of thyroid tests in ignorance of gestational age can mislead their interpretation, so the same women can be classified in normal or pathological TSH values only depending on their gestational age at the time of thyroid test in first trimester (39).

Additionally, most European countries remain mildly iodine deficient, and this should be taken into account when American guidelines are applied in Europe. The iodine intake might explain differences in TSH values among populations and whilst it would be ideal to only use women with optimal iodine intake to establish reference ranges in pregnancy (7), this would be challenging to undertake in Europe in the immediate future. Women should be counselled to ensure adequate iodine status during pregnancy.

The measurement of $\mathrm{T} 4$ concentration is also affected by the assay technology varying significantly by manufacturer. Assay method-specific and trimesterspecific reference ranges should be used for serum fT4, although other alternative methods have been proposed such as total T4 measurement or free thyroxine index (7).

Whilst the standardisation of thyroid function tests remains at present as an unattainable goal (40), the reference ranges are highly laboratory dependent and not applicable outside of its own clinical setting (37). In terms of pregnancy surveillance programmes, these factors need to be taken into consideration as laboratory 
reproducibility cannot be guaranteed. It is important to remark that the validity and repeatability of these tests are strongly constrained by these factors.

We should also reflect on what is the purpose for the screening of thyroid function during pregnancy: to detect thyroid diseases and to prevent adverse outcomes (15). If the genuine objective of screening is to identify those women at risk for pregnancy and/or perinatal complications, maybe we should reinforce the search for certain subgroups of women with history of adverse reproductive events: previous infertility, recurrent miscarriages or preterm delivery. In this regard, the Practice Committee of the American Society for Reproductive Medicine (ASRM) (41) include recommendations for the screening for thyroid abnormalities to evaluate recurrent pregnancy loss, but they do not establish an upper limit for TSH in pregnancy, and they also found insufficient evidence to recommend routine thyroxine (T4) testing or screening for antithyroid antibodies. Additionally, the most recent preventive strategies for preterm delivery do not include thyroid dysfunction as a potential and preventable risk factor $(42,43)$.

Even if we would implement the systematic determination of TSH and T4 in all pregnancies, we would not be able to reduce the incidence of obstetric complications associated to autoimmune thyroid disease (AITD) (44). Although the universal antithyroid antibodies testing during pregnancy has been published to be costeffective (19), its routine implementation in certain clinical settings (clinics, private practice) might not be appropriate in either economic or practical terms (45).

Additionally, the effectiveness of screening requires an early treatment in case of abnormal results of thyroid function tests. This would enforce the need for including the identification and management of thyroid dysfunction in pregnant women as competency of obstetricians and reproductive medicine specialists $(46,47)$.

In summary, before recommending a policy for universal screening of thyroid function at present, we should address our efforts to reach substantially closer agreements in management between endocrine and obstetric clinics.

\section{In favour of treating subclinical thyroid dysfunction}

The treatment in case of abnormal thyroid function test results ought to be a direct consequence of the universal screening policy. In this regard, levothyroxine therapy is unanimously recommended in cases of overt hypothyroidism $(4,5,6,7)$. However, for subclinical hypothyroidism $(\mathrm{SCH})$ or AITD, the recommendations from the guidelines have been experiencing frequent modifications to try to incorporate the best evidence available over the last decade.

Numerous observational studies and meta-analysis have demonstrated the association of $\mathrm{SCH}$ to adverse pregnancy and neonatal outcomes (Table 1) $(48,49,50$, $51,52,53,54,55,56,57)$, but the current guidelines show different recommendations for SCH: for ACOG (6) there is no evidence that identification and treatment of subclinical hypothyroidism during pregnancy improves outcomes. The Endocrine Society (4) and European Thyroid

Table 1 Meta-analysis and observational studies in cases of subclinical hypothyroidism in pregnancy.

\begin{tabular}{|c|c|c|}
\hline Study & Results & OR $(95 \% \mathrm{Cl})$ \\
\hline \multicolumn{3}{|c|}{ Meta-analysis } \\
\hline (48) & Miscarriage/pregnancy loss & $1.90(1.59-2.27)$ \\
\hline \multirow{5}{*}{ (49) } & Miscarriage/pregnancy loss & $2.01(1.66-2.44)$ \\
\hline & Preterm delivery & $1.20(0.97-1.50)$ \\
\hline & Growth restriction & $1.70(0.83-3.50)$ \\
\hline & Pre-eclampsia & $1.30(1.00-1.68)$ \\
\hline & Gestational diabetes & $1.28(0.90-1.81)$ \\
\hline$(50)$ & Growth restriction & $1.54(1.06-2.25)$ \\
\hline (51) & Gestational diabetes & $1.56(1.29-1.88)$ \\
\hline (52) & Gestational diabetes & $1.39(1.07-1.79)$ \\
\hline \multirow{3}{*}{$(53)$} & Pre-eclampsia & $1.70(1.10-2.64)$ \\
\hline & Gestational diabetes & $1.40(0.64-2.80)$ \\
\hline & Perinatal mortality & $2.7(1.60-4.72)$ \\
\hline \multicolumn{3}{|c|}{ Total range for OR: } \\
\hline & Miscarriage & $1.90-2.01$ \\
\hline & Preterm delivery & $1.20-1.81$ \\
\hline & Growth restriction & $1.54-3.36$ \\
\hline & Pre-eclampsia & $1.30-2.24$ \\
\hline & Gestational diabetes & $1.28-4.33$ \\
\hline \multicolumn{3}{|c|}{ Observational studies } \\
\hline$(54)$ & Gestational diabetes & $1.81(1.08-1.73)$ \\
\hline (55) & Preterm delivery & $1.81(1.02-3.28)$ \\
\hline \multirow[t]{2}{*}{ (56) } & Pre-eclampsia & $2.24(1.25-4.02)$ \\
\hline & Growth restriction & $3.36(1.75-6.38)$ \\
\hline \multirow[t]{2}{*}{$(57)$} & Growth restriction & $3.10(1.22-8.01)$ \\
\hline & Gestational diabetes & $4.33(2.10-8.91)$ \\
\hline \multicolumn{3}{|c|}{ TSH upper limit (mIU/L) } \\
\hline \multicolumn{2}{|c|}{ Screening before 20 weeks } & \\
\hline & $\begin{array}{l}\text { Screening before } 14 \text { weeks } \\
\text { of gestation }\end{array}$ & 2.5 \\
\hline & $\begin{array}{l}\text { Screening at any moment } \\
\text { during pregnancy }\end{array}$ & \\
\hline & 1st trimester & 3.47 \\
\hline & 2nd trimester & 3.81 \\
\hline & 3rd trimester & 4.99 \\
\hline & $\begin{array}{l}\text { Screening before } 15 \text { weeks } \\
\text { of gestation }\end{array}$ & 2.53 \\
\hline
\end{tabular}


Association (ETA) (5) guidelines endorse levothyroxine replacement independent of the presence of thyroid antibodies, although the recommendation level for obstetrical outcomes is weaker in women with $\mathrm{SCH}$ who are TPO Ab negative (Table 2). The new ATA guidelines (7) recommends, first, the evaluation of thyroperoxidase antibody (TPOAb) status in pregnant women with TSH concentrations $>2.5 \mathrm{IU} / \mathrm{L}$. Levothyroxine therapy is recommended for women who are positive for TPO-Abs with TSH greater than the pregnancy-specific reference range (strong recommendation, moderate quality evidence) and may be considered with TSH concentrations $>2.5 \mathrm{IU} / \mathrm{L}$ and below the upper limit of the pregnancyspecific reference range (weak recommendation, moderate quality evidence).

The recent ATA guidelines have taken into account that the combination of SCH and AITD is more likely to be associated with poorer obstetric outcomes $(58,59)$. This recommendation is supported by the most recent findings concerning the interrelationship between $\mathrm{SCH}$ and AITD: out of all TPOAb-positive women, those with the lowest TSH suppression by hCG have higher risk of adverse pregnancy outcomes than those women who respond to hCG stimulation normally (60).

When the interventional studies with levothyroxine performed so far are reviewed (Table 3) $(61,62,63,64$, $65,66,67,68,69,70,71,72,73,74,75,76)$, they seem to be more effective in preventing adverse obstetric events (mainly miscarriage and preterm delivery) in cases where AITD was present. All these studies have provided us with a more precise understanding of how to identify women at risk of developing pregnancy complications and will probably lead to better indications for therapy and consequently, more effective treatments. In this regard, systematic screening for TSH and TPOAb in women with a history of infertility or recurrent pregnancy losses needs to be considered, ideally before conception for maximum benefit.

For TPOAb-positive euthyroid women, the use of thyroxine might be offered individually in cases of assisted reproductive techniques (ART) (7), history of recurrent miscarriage (65) or preterm delivery (76), but there is no evidence of benefit in any other obstetric complications.

The identification of these targeted groups of women at risk of adverse outcomes should be considered by reproductive medicine specialists as a priority, since thyroid dysfunction can jeopardize pregnancy viability and early treatment might substantially improve the rates of successfully completed pregnancies $(65,76)$.
Recurrent miscarriage and preterm delivery are highly prevalent entities in Obstetrics $(39,40,41)$, which result in tremendous social and economic burdens (77, 78). At present, much effort is being invested in order to reduce their impact on families and health services. In this regard, the recent results of levothyroxine use in reducing pregnancy loss and preterm delivery are certainly promising $(11,76)$. However, it is important to highlight that all the interventions with levothyroxine (LT4) replacement performed to date did not include any other preventive or therapeutic approach: data are lacking regarding the effectiveness of LT4 in combination with aspirin for recurrent miscarriages or progesterone and/or pessary for preterm delivery; and these approaches should be evaluated through further studies.

It might be argued that levothyroxine therapy is indicated in select cases of mild thyroid hypofunction during pregnancy and its effectiveness in preventing obstetric complications might be greater if earlier onset, association to other drugs and dosage adjustment are optimized (79).

In summary, the indications for LT4 therapy needs to be considered, taking into account the evidence available and on a case-by-case assessment of obstetric risk factors (Table 2).

\section{Against treating subclinical thyroid dysfunction}

There are solid arguments to treat overt hypothyroidism at any stage of life and, particularly, during pregnancy in order to prevent serious adverse effects to the fetus (80). Nevertheless, a worrying percentage of levothyroxinetreated women do not receive a careful preconception adjustment to optimize thyroid function before pregnancy (81) or advice to use contraception until achievement of a euthyroid state before conceiving (82) or even they demonstrate low adherence to treatment during pregnancy (83). According to this, it would seem more reasonable to persevere with the optimization of treatment for overt hypothyroidism during the preconception stage and at early gestation than focus attention on subtle alterations in thyroid function tests (84).

Furthermore, two large-scale trials were carried out to investigate the effectiveness of levothyroxine therapy during pregnancy to ameliorate the cognitive function in children $(8,9)$. None of these studies have shown a significant effect of $\mathrm{LT}_{4}$ on preventing adverse cognitive outcomes, though both studies performed a late 
Table 2 Indications for treatment with levothyroxine during pregnancy according to the main outcomes.

\begin{tabular}{|c|c|c|c|}
\hline & Recommendation & Pros & Cons \\
\hline \multicolumn{4}{|l|}{ Pregnancy outcomes } \\
\hline \multicolumn{4}{|l|}{ TPOAb positive } \\
\hline $\mathrm{TSH}>10 \mathrm{IU} / \mathrm{L}$ & $\begin{array}{l}\text { LT4 therapy is strongly } \\
\text { recommended }\end{array}$ & $\begin{array}{l}\text { Treatment of overt } \\
\text { hypothyroidism reduces the risk } \\
\text { of pregnancy complications }\end{array}$ & None \\
\hline TSH 4.0-10.0 IU/L & $\begin{array}{l}\text { LT4 therapy is } \\
\text { recommended }\end{array}$ & $\begin{array}{l}\text { Treatment in this group reduces } \\
\text { the risk of pregnancy } \\
\text { complications and evolution to } \\
\text { overt hypothyroidism }\end{array}$ & $\begin{array}{l}\text { LT4 therapy need to be monitored } \\
\text { in order to avoid sub/ } \\
\text { overtreatment }\end{array}$ \\
\hline TSH 2.5-4.0 IU/L & $\begin{array}{l}\text { LT4 therapy may be } \\
\text { considered }\end{array}$ & $\begin{array}{l}\text { Treatment should be restricted to } \\
\text { high risk of pregnancy } \\
\text { complications such as infertility } \\
\text { or recurrent pregnancy loss } \\
\text { (weak evidence for preterm } \\
\text { delivery) }\end{array}$ & $\begin{array}{l}\text { - Weak recommendation } \\
\text { - High risk of overtreatment } \\
\text { - No evidence of effectiveness for: } \\
\text { - Gestational diabetes } \\
\text { - Hypertensive disorders } \\
\text { - Growth restriction }\end{array}$ \\
\hline $\mathrm{TSH}<2.5 \mathrm{IU} / \mathrm{L}$ & $\begin{array}{l}\text { LT4 therapy is not } \\
\text { recommended }\end{array}$ & $\begin{array}{l}\text { Treatment should be restricted to } \\
\text { high risk of pregnancy } \\
\text { complications such as infertility, } \\
\text { ART or recurrent pregnancy loss } \\
\text { and considered on a case-by- } \\
\text { case basis }\end{array}$ & $\begin{array}{l}\text { There is insufficient evidence to } \\
\text { conclusively determine if LT4 } \\
\text { therapy improves fertility or } \\
\text { decreases pregnancy loss risk in } \\
\text { TPOAb positive, euthyroid } \\
\text { women }\end{array}$ \\
\hline \multicolumn{4}{|l|}{ TPOAb negative } \\
\hline $\mathrm{TSH}>10 \mathrm{IU} / \mathrm{L}$ & $\begin{array}{l}\text { LT4 therapy is strongly } \\
\text { recommended }\end{array}$ & $\begin{array}{l}\text { TSH }>10 \text { IU/L can be considered as } \\
\text { overt hypothyroidism }\end{array}$ & The quality of evidence is low \\
\hline TSH 4.0-10.0 IU/L & $\begin{array}{l}\text { LT4 therapy is } \\
\text { recommended }\end{array}$ & $\begin{array}{l}\text { Similar adverse risk to } \mathrm{SCH} \text { and } \\
\text { TPOAb positive when TSH } \\
\text { exceeds 5-10 IU/L }\end{array}$ & $\begin{array}{l}\text { - Weak recommendation } \\
\text { - The quality of evidence is low } \\
\text { - Treatment should be considered } \\
\text { with caution if reference ranges } \\
\text { are not available }\end{array}$ \\
\hline TSH 2.5-4.0 IU/L & $\begin{array}{l}\text { LT4 therapy should not } \\
\text { be used }\end{array}$ & $\begin{array}{l}\text { Low dose LT4 can be used in } \\
\text { women undergoing IVF or ICSI, } \\
\text { in order to achieve a TSH } \\
<2.5 \mathrm{IU} / \mathrm{L}\end{array}$ & $\begin{array}{l}\text { There is insufficient evidence to } \\
\text { determine if LT4 therapy } \\
\text { improves fertility in TPOAb } \\
\text { negative, euthyroid women }\end{array}$ \\
\hline $\mathrm{TSH}<2.5 \mathrm{IU} / \mathrm{L}$ & $\begin{array}{l}\text { LT4 therapy is not } \\
\text { recommended }\end{array}$ & None & $\begin{array}{l}\text { - Strong recommendation against } \\
\text { the use of LT4 in this situation } \\
\text { - Potential risks of iatrogenic use } \\
\text { of thyroxine in pregnancy: } \\
\text { - Growth restriction } \\
\text { - Abnormal brain } \\
\text { morphology in children }\end{array}$ \\
\hline \multicolumn{4}{|c|}{ Cognitive function in offspring } \\
\hline $\mathrm{TSH}>10 \mathrm{IU} / \mathrm{L}$ & $\begin{array}{l}\text { LT4 therapy is strongly } \\
\text { recommended }\end{array}$ & $\begin{array}{l}\text { Untreated high TSH levels have } \\
\text { been associated to lower IQ } \\
\text { scores, independently of the test }\end{array}$ & $\begin{array}{l}\text { The effectiveness of LT4 therapy } \\
\text { on fetal neurodevelopment is } \\
\text { limited to an early intervention } \\
\text { (during first trimester) }\end{array}$ \\
\hline TSH 4.0-10.0 IU/L & $\begin{array}{l}\text { LT4 therapy is } \\
\text { recommended }\end{array}$ & $\begin{array}{l}\text { Early onset of LT4 treatment can } \\
\text { improve cognitive function in } \\
\text { offspring }\end{array}$ & $\begin{array}{l}\text { The effectiveness of LT4 treatment } \\
\text { has not yet conclusively } \\
\text { demonstrated in terms of } \\
\text { cognitive outcomes }\end{array}$ \\
\hline TSH 2.5-4.0 IU/L & $\begin{array}{l}\text { LT4 therapy should not } \\
\text { be used }\end{array}$ & None & $\begin{array}{l}\text { - High risk of overtreatment } \\
\text { - No evidence of effectiveness on } \\
\text { cognitive outcomes }\end{array}$ \\
\hline $\mathrm{TSH}<2.5 \mathrm{IU} / \mathrm{L}$ & $\begin{array}{l}\text { LT4 therapy is not } \\
\text { recommended }\end{array}$ & None & $\begin{array}{l}\text { - Strong recommendation against } \\
\text { the use of LT4 in this situation- } \\
\text { Potential risks of iatrogenic use } \\
\text { of thyroxine in pregnancy: } \\
\text { - Growth restriction } \\
\text { - Abnormal brain } \\
\text { morphology in children }\end{array}$ \\
\hline
\end{tabular}


intervention (at the end of first trimester or later), which might limit their effectiveness when compared with early treatment (85). Some interventional studies with levothyroxine offered optimistic findings (Table 3), but others have not found significant differences in adverse pregnancy events between treated and untreated groups $(14,71,73,75)$ in cases of SCH and/or AITD.

Before considering levothyroxine therapy in cases of mild thyroid dysfunction, we should review how many shortcomings are present in this recommendation. First of all, we need reliable diagnostic criteria to identify $\mathrm{SCH}$ properly, specifically adjusted by gestational age and population based. As we have previously indicated, the availability of own reference ranges is the real Achilles' heel for a responsible screening policy in many centres. After that, a search for TPO antibodies should be done, in order to determine the existence of autoimmunity, according to the recent ATA guidelines (7); therefore, the onset of treatment and its potential effectiveness would be conditioned to the elapsed time until the complete assessment of thyroid function.

In clinical settings, where reference range are not available, the treatment for $\mathrm{SCH}$ should be considered with caution (TSH $>4$ IU/L or TPOAb positive with TSH $>2.5 \mathrm{IU} / \mathrm{L}$ ) (7). Although the use of thyroxine might potentially reduce miscarriage or preterm delivery rates, there is no evidence of effectiveness for gestational diabetes, hypertensive disorders (10) or infant cognitive function $(8,9)$. The use of levothyroxine in case of AITD with normal thyroid function is not currently recommended by any scientific society $(4,5,6,7)$, although ATA guidelines consider the use of thyroxine in cases of TPOAb positive with TSH $>2.5 \mathrm{IU} / \mathrm{L}$.

However, a TSH cut-off of $2.5 \mathrm{IU} / \mathrm{L}$ or $4.5 \mathrm{IU} / \mathrm{L}$ in women who underwent in vitro fertilisation (FIV) (86) or intrauterine insemination (87) did not show differences in the rates of clinical pregnancy, delivery or miscarriage. These results are in consonance with the hypothesis that the risk of adverse pregnancy outcomes is lower in women with a relatively normal response to hCG (60) as must occur in successful cycles in assisted reproduction. The empirical use of levothyroxine in women with history of infertility or before ART is not currently justified.

Finally, the risk of overtreatment has become a concerning issue inherent to the overuse of levothyroxine in obstetric practices $(88,89)$. Regarding the effects of additional levothyroxine supply on the fetus, there are no currently available fetal markers to monitor the utero-placental passage of $\mathrm{LT}_{4}$ (90). However, samples of fetal blood obtained by cordocentesis showed free $\mathrm{T} 4$ levels concentrations higher than normal levels in around 60\% of fetuses from euthyroid mothers with AITD who had received levothyroxine (91). Thyroid hormones would have a U-shaped effect on fetal development, particularly the fetal brain development so as both deficiency and excess might impair fetal neurodevelopment (25). High maternal free $\mathrm{LT}_{4}$ concentrations have been associated to lower child IQ and lower grey matter and cortex volume (34).

The high free $\mathrm{LT}_{4}$ levels in maternal blood have also been associated to low birth weight and an increased risk for small for gestational age (SGA) newborns (92). Additionally, a recent national survey in USA showed that thyroid hormone treatment was associated with decreased risk of pregnancy loss in women with subclinical hypothyroidism, but increased risk of other pregnancyrelated adverse outcomes such as preterm delivery, gestational diabetes or pre-eclampsia (11). All these data highlight the need of selective indications of therapy, based on sensible treatment threshold for women who have mildly increased TSH without other risk factors.

In summary, it is highly likely that both overt hypothyroidism and the combination of subclinical hypothyroidism and TPOAb positivity may jeopardize pregnancy outcomes and which detection and treatment with LT4 would ameliorate. Nevertheless, the need of treatment in cases of mild SCH with TPOAbs negative remains controversial, particularly with regard to cognitive outcomes.

Further scientific evidence is needed regarding the effectiveness of LT4 therapy in euthyroid, TPOAbspositive women in improving fertility in cases of ART, as well as in preventing miscarriage and/or preterm delivery. In this regard, new randomized controlled trials with timely onset of treatment with LT4 are expected.

\section{Conclusion}

In order to increase the safety and effectiveness of levothyroxine treatment in obstetric practices, some key issues have to be addressed: the establishment of welldefined criteria for diagnosis adapted to every single population, laboratory and trimester of gestation; the acquisition of management skills in interpreting abnormal thyroid function tests by obstetricians; the inclusion of 
Table 3 Interventional studies with levothyroxine in subclinical hypothyroidism and/or thyroid autoimmunity during pregnancy.

\begin{tabular}{|c|c|c|}
\hline Study & Design & Intervention \\
\hline (61) & Meta-analysis & $\begin{array}{l}\text { Studies on SCH included: (62), } \\
\text { (58); } 5 \text { studies reported on the } \\
\text { effect of } \mathrm{LT}_{4} \text { therapy for AITD }\end{array}$ \\
\hline (14) & $\begin{array}{l}\text { Prospective } \\
\text { Non-randomised }\end{array}$ & $\begin{array}{l}53 \text { pregnancies from } 34 \text { patients } \\
\text { TPO Ab (+) with recurrent } \\
\text { miscarriage: } \\
\text { - } 17 \text { pregnancies with } \mathrm{LT}_{4} \\
\text { treatment } \\
\text { - } 36 \text { pregnancies without } \\
\text { treatment }\end{array}$ \\
\hline (63) & Retrospective & $\begin{array}{l}\text { 96 TPO Ab (+) pregnant women } \\
-49 \text { treated with } \mathrm{LT}_{4} \\
-47 \text { no treated }\end{array}$ \\
\hline (10) & Meta-analysis & $\begin{array}{l}\text { Studies on SCH included: (64), N } \\
(65),(66)(67)\end{array}$ \\
\hline
\end{tabular}

(28) Meta-analysis

(71) Prospective Non-randomised recurrent early pregnancy loss -24 treated with $\mathrm{LT}_{4}$

-15 no treated

(72) Prospective Cost-effectiveness analysis of Non-randomised screening and treatment after (SpA

$73 \mathrm{SCH}$ and/or TAl treated with $\mathrm{LT}_{4}$

$38 \mathrm{SCH}$ and/or TAl untreated

(73) Prospective Non-randomised

Women with 2 or more

consecutive miscarriages

31 with AITD and 27 with SCH were treated with $\mathrm{LT}_{4}$

compared to 100 healthy women without a history of miscarriage

Screening group (675

(12) Prospective Non-randomised

pregnancies) was compared to control group (996 pregnancies) $105 \mathrm{SCH}$ from screening group were treated with $\mathrm{LT}_{4}$ $252 \mathrm{SCH}$ from control group did not receive treatment

(74) Retrospective 82 women with $\mathrm{SCH}$ were treated

284 women with $\mathrm{SCH}$ did not received treatment with $\mathrm{LT}_{4}$

(75) Prospective Randomised

(76) Prospective Randomised

(11) Retrospective

198 euthyroid, AITD (+) treated

with $\mathrm{LT}_{4}$

195 euthyroid, AITD (+)

untreated

197 euthyroid, AITD (-)

untreated

$65 \mathrm{TPO} A \mathrm{~b}(+)$ women treated

with $\mathrm{LT}_{4}$

66 TPO Ab (+) women untreated.

131 TPO Ab (-) women

untreated

843 women with $\mathrm{SCH}$ were

\section{Results}

SCH: $\downarrow$ Miscarriage, $\downarrow$ Preterm delivery,

TAI: Miscarriage (not significant), $\downarrow$ Preterm delivery

No significant difference in the outcome between groups in live birth rate

\section{$\downarrow$ Miscarriage rate}

$\downarrow$ Preterm delivery,

No effect on pre-eclampsia

$\uparrow$ Delivery rate,

$\downarrow$ Miscarriage rate

No significant difference in the outcome between groups in live birth rate

$\uparrow$ Successfully completed subsequent pregnancies

Following $\mathrm{LT}_{4}$ treatment, No difference in miscarriage rate between hypothyroid and euthyroid individuals in TPO Ab

$(+)$ women

$\downarrow$ Miscarriage rate,

$\downarrow$ Fetal macrosomia risk,

$\uparrow$ Cesarean risk

treated

4562 women with SCH did not received treatment with LT4 $\downarrow$ Risk of low birth weight,

$\downarrow$ Risk of low Apgar score

No significant difference in miscarriage or preterm delivery rate between the 3 groups

$\downarrow$ Preterm delivery rate

$\downarrow$ Pregnancy loss,

$\uparrow$ Preterm delivery,

$\uparrow$ Gestational diabetes,

$\uparrow$ Pre-eclampsia

\section{Comments}

Conclusion: For SCH and AITD, evidence is insufficient to recommend treatment with thyroxine

Empirical thyroxine therapy in

TPOAb(+) pregnant women did not seem to improve outcome

Potential benefit of universal screening and $\mathrm{LT}_{4}$ treatment in pregnant women with TAI

There was a trend towards reduced risk of miscarriage with $\mathrm{LT}_{4}$, but did not reach statistical significance

In an ART setting, no data are available on the effects of $\mathrm{LT}_{4}$ treatment on preterm delivery or pre-eclampsia

The prevalence of $\mathrm{SCH}$ in thisREPL cohort was $19 \%$

Screening for thyroid disorders in women after SpA and treatment with $\mathrm{LT}_{4}$ is costsaving and it improves the subsequent pregnancy rate

The prevalence of AITD was higher in pregnant women with a history of recurrent miscarriage compared with healthy pregnant control population

Screening and intervention of $\mathrm{SCH}$ can reduce the risk of miscarriage

No significant differences were observed in other pregnancy outcomes between the two groups

Other pregnancy-related adverse outcomes were similar between the two groups

Levothyroxine intervention had no impact on the rate of miscarriage or preterm delivery in euthyroid TAI (+) women

The number needed to treat (NNT) for preterm birth was 1.7

The adjusted odd of pregnancy loss were lower in treated women than in untreated women if their pre-treatment TSH concentration was $4.1-10 \mathrm{mIU} / \mathrm{L}$ 
thyroid dysfunction as plausible cause for some obstetric complications in the algorithms in clinical decisionmaking and to have more joint endocrine and obstetric clinics. Each of these conditions needs substantial progress at present.

\section{Details of ethics approval}

The authors declare compliance with ethical standards for reviews.

\section{Declaration of interest}

The authors declare that there is no conflict of interest that could be perceived as prejudicing the impartiality of this debate.

\section{Funding}

This research received no specific grant from any funding agency in the public, commercial or not-for-profit sectors.

\section{Author contribution statement}

Inés Velasco and Peter Taylor equally prepared, drafted and refined the manuscript.

\section{Acknowledgements}

The authors sincerely thank the Virtual Library from Public Health System of Andalusia for providing us with information resources to complete this review.

\section{References}

1 Springer D, Jiskra J, Limanova Z, Zima T \& Potlukova E. Thyroid in pregnancy: from physiology to screening. Critical Reviews in Clinical Laboratory Sciences 201754 102-116. (https://doi.org/10.1080/10408 363.2016.1269309)

2 Stagnaro-Green A. Clinical guidelines: thyroid and pregnancy time for universal screening? Nature Reviews Endocrinology 201713 192-194. (https://doi.org/10.1038/nrendo.2017.17)

3 Pop VJ. Pregnancy, postpartum and the thyroid: isn't it time to offer women optimal care? Facts, Views and Vision in Obstetrics and Gynaecolgy 20146 166-170.

4 De Groot L, Abalovich M, Alexander EK, Amino N, Barbour L, Cobin RH, Eastman CJ, Lazarus JH, Luton D, Mandel SJ et al. Management of thyroid dysfunction during pregnancy and postpartum: an Endocrine Society clinical practice guideline. Journal of Clinical Endocrinology and Metabolism 201297 2543-2565. (https:// doi.org/10.1210/jc.2011-2803)

5 Lazarus J, Brown RS, Daumerie C, Hubalewska-Dydejczyk A, Negro R \& Vaidya B. 2014 European thyroid association guidelines for the management of subclinical hypothyroidism in pregnancy and in children. European Thyroid Journal 20143 76-94. (https://doi. org/10.1159/000362597)

6 The American College of Obstetricians and Gynecologists. Practice Bulletin No. 148: thyroid disease in pregnancy. Obstetrics and Gynecology 2015125 996-1005. (https://doi.org/10.1097/01. AOG.0000462945.27539.93)

7 Alexander EK, Pearce EN, Brent GA, Brown RS, Chen H, Dosiou C, Grobman WA, Laurberg P, Lazarus JH, Mandel SJ et al. 2017 Guidelines of the American Thyroid Association for the Diagnosis and Management of thyroid disease during pregnancy and the postpartum. Thyroid 201727 315-389. (https://doi.org/10.1089/ thy.2016.0457)

8 Lazarus JH, Bestwick JP, Channon S, Paradice R, Maina A, Rees R, Chiusano E, John R, Guaraldo V, George LM et al. Antenatal thyroid screening and childhood cognitive impairment. New England Journal of Medicine 2012366 493-501. (https://doi.org/10.1056/ NEJMoa1106104)

9 Casey BM, Thom EA, Peaceman AM, Varner MW, Sorokin Y, Hirtz DG, Reddy UM, Wapner RJ, Thorp JM Jr, Saade G et al. Treatment of Subclinical Hypothyroidism or Hypothyroxinemia in Pregnancy. New England Journal of Medicine 2017376 815-825. (https://doi.org/10.1056/NEJMoa1606205)

10 Reid SM, Middleton P, Cossich MC, Crowther CA \& Bain E. Interventions for clinical and subclinical hypothyroidism pre-pregnancy and during pregnancy (Review). Cochrane Database of Systematic Reviews 20135 CD007752. (https://doi. org/10.1002/14651858.CD007752.pub3)

11 Maraka S, Mwangi R, McCoy RG, Yao X, Sangaralingham LR, Singh Ospina NM, O'Keeffe DT, De Ycaza AE, Rodriguez-Gutierrez R, Coddington CC 3rd et al. Thyroid hormone treatment among pregnant women with subclinical hypothyroidism: US National Assessment. BMJ 2017356 i6865. (https://doi.org/10.1136/bmj. i6865)

12 Ma L, Qi H, Chai X, Jiang F, Mao S, Liu J, Zhang S, Lian X, Sun X, Wang D et al. The effects of screening and intervention of subclinical hypothyroidism on pregnancy outcomes: a prospective multicenter single-blind, randomized, controlled study of thyroid function screening test during pregnancy. Journal of MaternalFetal and Neonatal Medicine 201629 1391-1394. (https://doi.org/ $0.3109 / 14767058.2015 .1049150)$

13 Chan S \& Boelaert K. Optimal management of hypothyroidism, hypothyroxinaemia and euthyroid TPO antibody positivity preconception and in pregnancy. Clinical Endocrinology 201582 313-326. (https://doi.org/10.1111/cen.12605)

14 Yan J, Sripada S, Saravelos SH, Chen ZJ, Egner W \& Li TC. Thyroid peroxidase antibody in women with unexplained recurrent miscarriage: prevalence, prognostic value, and response to empirical thyroxine therapy. Fertility and Sterility 201298 378-382. (https:// doi.org/10.1016/j.fertnstert.2012.04.025)

15 Vila L, Velasco I, González S, Morales F, Sánchez E, Torrejón S, Soldevila B, Stagnaro-Green A \& Puig-Domingo M. Controversies in endocrinology: on the need for universal thyroid screening in pregnant women. European Journal of Endocrinology $2014 \mathbf{1 7 0}$ R17-R30. (https://doi.org/10.1530/EJE-13-0561)

16 Chen I. Prenatal testing of thyroid is debated. The New York Times. (available at: http://www.nytimes.com/2009/04/14/health/14thyr. html)

17 Beaglehole R, Bonita R \& Kjellström T. Basic Epidemiology. Geneva: World Health Organization, 1993. (https://doi. org/10.1111/j.1365-2923.1992.tb00210.x)

18 Wilson J \& Jungner G. Principles and Practice of Screening for Disease. Geneva: World Health Organization, 1968. Public Health papers 34, 2011.

19 Dosiou C, Barnes J, Schwartz A, Negro R, Crapo L \& StagnaroGreen A. Cost-effectiveness of universal and risk-based screening for autoimmune thyroid disease in pregnant women. Journal of Clinical Endocrinology and Metabolism 201297 1536-1546. (https://doi. org/10.1210/jc.2011-2884)

20 Bryant SN, Nelson DB, McIntire DD, Casey BM \& Cunningham FG. An analysis of population-based prenatal screening for overt hypothyroidism. American Journal of Obstetrics and Gynecology 2015213 565.e1-565.e6. (https://doi. org/10.1016/j.ajog.2015.06.061)

21 Nazarpour S, Tehrani FR, Simbar M, Tohidi M, AlaviMajd H $\&$ Azizi F. Comparison of universal screening with targeted 
high-risk case finding for diagnosis of thyroid disorders European Journal of Endocrinology 2016174 77-83. (https://doi. org/10.1530/EJE-15-0750)

22 Horacek J, Spitalnikova S, Dlabalova B, Malirova E, Vizda J, Svilias I, Cepkova J, Mc Grath C \& Maly J. Universal screening detects twotimes more thyroid disorders in early pregnancy than targeted highrisk case finding. European Journal of Endocrinology 2010163 645-650. (https://doi.org/10.1530/EJE-10-0516)

23 Stagnaro-Green A \& Pearce E. Thyroid disorders in pregnancy. Nature Review Endocrinology 20128 650-658. (https://doi.org/10.1038/ nrendo.2012.171)

24 Hanson MA \& Gluckman PD. Early developmental conditioning of later health and disease: physiology or pathophysiology? Physiological Reviews 201494 1027-1076. (https://doi.org/10.1152/ physrev.00029.2013)

25 Andersen SL, Carlé A, Karmisholt J, Pedersen IB \& Andersen S. Mechanisms in Endocrinology: neurodevelopmental disorders in children born to mothers with thyroid dysfunction: evidence of fetal programming? European Journal of Endocrinology 2017177 R27-R36. (https://doi.org/10.1530/EJE-16-0947)

26 Thung SF, Funai EF \& Grobman WA. The cost-effectiveness of universal screening in pregnancy for subclinical hypothyroidism American Journal of Obstetrics and Gynecology 2009200 267.e1-267.e7. (https://doi.org/10.1016/j.ajog.2008.10.035)

27 Heindel JJ \& Vandenberg LN. Developmental origins of health and disease: a paradigm for understanding disease cause and prevention. Current Opinion in Pediatrics 201527 248-253 (https://doi. org/10.1097/MOP.0000000000000191)

28 Velkeniers B, Van Meerhaeghe A, Poppe K, Unuane D, Tournaye H $\&$ Haentjens P. Levothyroxine treatment and pregnancy outcome in women with subclinical hypothyroidism undergoing assisted reproduction technologies: systematic review and meta-analysis of RCTs. Human Reproduction Update 201319 251-258. (https://doi. org/10.1093/humupd/dms052)

29 Green KA, Werner MD, Franasiak JM, Juneau CR, Hong KH \& Scott RT Jr. Investigating the optimal preconception TSH range for patients undergoing IVF when controlling for embryo quality. Journal of Assisted Reproduction and Genetics 201532 1469-1476. (https://doi. org/10.1007/s10815-015-0549-4)

30 Hammond KR, Cataldo NA, Hubbard JA, Malizia BA \& Steinkampf MP. Gestational hypothyroidism: development of mild hypothyroidism in early pregnancy in previously euthyroid women. Fertility and Sterility 2015103 1532.e1-1536.e1. (https://doi org/10.1016/j.fertnstert.2015.03.006)

31 Li C, Shan Z, Mao J, Wang W, Xie X, Zhou W, Li C, Xu B, Bi L, Meng $T$ et al. Assessment of thyroid function during first-trimester pregnancy: what is the rational upper limit of serum TSH during the first trimester in Chinese pregnant women? Journal of Clinical Endocrinology and Metabolism 201499 73-79. (https://doi. org/10.1210/jc.2013-1674)

32 Medici M, Korevaar TI, Visser WE, Visser TJ \& Peeters RP. Thyroid function in pregnancy: what is normal? Clinical Chemistry $20156 \mathbf{6 1}$ 704-713. (https://doi.org/10.1373/clinchem.2014.236646)

33 Stagnaro-Green A, Abalovich M, Alexander E, Azizi F, Mestman J, Negro R, Nixon A, Pearce EN, Soldin OP, Sullivan S et al. Guidelines of the American Thyroid Association for the diagnosis and management of thyroid disease during pregnancy and postpartum. Thyroid 201121 1081-1125. (https://doi.org/10.1089/ thy.2011.0087)

34 Korevaar T, Muetzel R, Medici M, Chaker L, Jaddoe VW, de Rijke YB, Steegers EA, Visser TJ, White T, Tiemeier H et al. Association of maternal thyroid function during early pregnancy with off spring IQ and brain morphology in childhood: a population-based prospective cohort study. Lancet Diabetes and Endocrinology $2016435-43$. (https://doi.org/10.1016/S2213-8587(15)00327-7)
35 Taylor PN, Okosieme OE, Premawardhana L \& Lazarus JH. Should all women be screened for thyroid dysfunction in pregnancy? Women's Health 201511 295-307. (https://doi.org/10.2217/WHE.15.7)

36 Korevaar TI, de Rijke YB, Chaker L, Medici M, Jaddoe VW, Steegers EA, Visser TJ \& Peeters RP. Stimulation of thyroid function by human chorionic gonadotropin during pregnancy: a risk factor for thyroid disease and a mechanism for known risk factors. Thyroid 201727 440-450. (https://doi.org/10.1089/thy.2016.0527)

37 Bliddal S, Feldt-Rasmussen U, Boas M, Faber J, Juul A, Larsen T \& Precht DH. Gestational age-specific reference ranges from different laboratories misclassify pregnant women's thyroid status: comparison of two longitudinal prospective cohort studies. European Journal of Endocrinology 2013170 329-339. (https://doi.org/10.1530/EJE-13-0672)

38 Laurberg P, Andersen SL, Hindersson P, Nohr EA \& Olsen J. Dynamics and predictors of serum tsh and $\mathrm{ft} 4$ reference limits in early pregnancy: a study within the Danish National Birth Cohort. Journal of Clinical Endocrinology and Metabolism 2016101 2484-2492. (https://doi.org/10.1210/jc.2016-1387)

39 Murillo-Llorente M, Fajardo-Montañana C, Pérez-Bermejo M, VilaCandel R, Gómez-Vela J \& Velasco I. Intra-individual variability in TSH levels of healthy women during the first half of pregnancy. Endocrinología, Diabetes y Nutrición 201764 288-294. (https://doi. org/10.1016/j.endinu.2017.04.002)

40 Thienpont LM, Faix JD \& Beastall G. Standardization of free thyroxine and harmonization of thyrotropin measurements: a request for input from endocrinologists and other physicians. Thyroid 201525 1379-1380. (https://doi.org/10.1089/thy.2015.0309)

41 Practice Committee of the American Society for Reproductive Medicine. Evaluation and treatment of recurrent pregnancy loss: a committee opinion. Fertility and Sterility 201298 1103-1111. (https:// doi.org/10.1016/j.fertnstert.2012.06.048)

42 van Zijl MD, Koullali B, Mol BW, Pajkrt E, \& Oudijk MA. Prevention of preterm delivery: current challenges and future prospects. International Journal of Women's Health 20168 633-645. (https://doi. org/10.2147/IJWH.S89317)

43 Sananès N, Langer B, Gaudineau A, Kutnahorsky R, Aissi G, Fritz G, Boudier E, Viville B, Nisand I \& Favre R. Prediction of spontaneous preterm delivery in singleton pregnancies: where are we and where are we going? A review of literature. Journal of Obstetrics and Gynaecology 201434 457-461. (https://doi.org/10.3109/01443615.20 14.896325)

44 Crawford NM \& Steiner AZ. Thyroid autoimmunity and reproductive function. Seminars in Reproductive Medicine 201634 343-350. (https:// doi.org/10.1055/s-0036-1593485)

45 Toubert ME, Chevret S, Cassinat B, Schlageter MH, Beressi JP \& Rain JD. From guidelines to hospital practice: reducing inappropriate ordering of thyroid hormone and antibody tests. European Journal of Endocrinology 2000142 605-610. (https://doi.org/10.1530/ eje.0.1420605)

46 Kut A, Kalli H, Anil C, Mousa U \& Gursoy A. Knowledge, attitudes and behaviors of physicians towards thyroid disorders and iodine requirements in pregnancy. Journal of Endocrinological Investigation 201538 1057-1064. (https://doi.org/10.1007/s40618-015-0275-x)

47 Rinaldi MD \& Stagnaro-Green AS. Thyroid disease and pregnancy: degrees of knowledge. Thyroid 200717 747-753. (https://doi. org/10.1089/thy.2007.0080)

48 Zhang Y, Wang H, Pan X, Teng W \& Shan Z. Patients with subclinical hypothyroidism before 20 weeks of pregnancy have a higher risk of miscarriage: a systematic review and meta-analysis. PLoS ONE 2017 12 e0175708. (https://doi.org/10.1371/journal.pone.0175708)

49 Maraka S, Ospina NMS, O'Keeffe DT, Espinosa De Ycaza AE, Gionfriddo MR, Erwin PJ, Coddington CC 3rd, Stan MN, Murad MH $\&$ Montori VM. Subclinical hypothyroidism in pregnancy: a systematic review and meta-analysis. Thyroid 201626 580-590. (https://doi.org/10.1089/thy.2015.0418) 
50 Tong Z, Xiaowen Z, Baomin C, Aihua L, Yingying Z, Weiping T \& Zhongyan $S$. The effect of subclinical maternal thyroid dysfunction and autoimmunity on intrauterine growth restriction: a systematic review and meta-analysis. Medicine 201695 e3677. (https://doi. org/10.1097/MD.0000000000003677)

51 Gong LL, Liu H \& Liu LH. Relationship between hypothyroidism and the incidence of gestational diabetes: a meta-analysis. Taiwanese Journal of Obstetrics and Gynecology 201655 171-175. (https://doi. org/10.1016/j.tjog.2016.02.004)

52 Toulis KA, Stagnaro-Green A \& Negro R. Maternal subclinical hypothyroidsm and gestational diabetes mellitus: a meta-analysis. Endocrine Practices 201420 703-714. (https://doi.org/10.4158/ EP13440.RA)

53 van den Boogaard E, Vissenberg R, Land JA, van Wely M, van der Post JAM, Godding M \& Bisschop PH. Significance of (sub)clinical thyroid dysfunction and thyroid autoimmunity before conception and in early pregnancy: a systematic review. Human Reproduction Update 201622 532-533. (https://doi.org/10.1093/humupd/ dmw003)

54 Ying H, Tang YP, Bao YR, Su XJ, Cai X, Li YH \& Wang DF. Maternal TSH level and TPOAb status in early pregnancy and their relationship to the risk of gestational diabetes mellitus. Endocrine $2016 \mathbf{5 4}$ 742-750. (https://doi.org/10.1007/s12020-016-1022-6)

55 Arbib N, Hadar E, Sneh-Arbib O, Chen R, Wiznitzer A \& GabbayBenziv R. First trimester thyroid stimulating hormone as an independent risk factor for adverse pregnancy outcome. Journal of Maternal-Fetal and Neonatal Medicine 201730 2174-2178. (https:// doi.org/10.1080/14767058.2016.1242123)

56 Chen LM, Du WJ, Dai J, Zhang Q, Si GX, Yang H, Ye EL, Chen QS, Yu LC, Zhang C et al. Effects of subclinical hypothyroidism on maternal and perinatal outcomes during pregnancy: a single-center cohort study of a Chinese population. PLoS ONE 20149 e109364. (https://doi.org/10.1371/journal.pone.0109364)

57 Karakosta P, Alegakis D, Georgiou V, Roumeliotaki T, Fthenou E, Vassilaki M, Boumpas D, Castanas E, Kogevinas M \& Chatzi L. Thyroid dysfunction and autoantibodies in early pregnancy are associated with increased risk of gestational diabetes and adverse birth outcomes. Journal of Clinical Endocrinology and Metabolism 2012 97 4464-4472. (https://doi.org/10.1210/jc.2012-2540)

58 Negro R, Schwartz A, Gismondi R, Tinelli A, Mangieri T \& StagnaroGreen A. Universal screening versus case finding for detection and treatment of thyroid hormonal dysfunction during pregnancy. Journal of Clinical Endocrinology and Metabolism 201095 1699-1707. (https://doi.org/10.1210/jc.2009-2009)

59 Liu H, Shan Z, Li C, Mao J, Xie X, Wang W, Fan C, Wang H, Zhang H, Han C et al. Maternal subclinical hypothyroidism, thyroid autoimmunity, and the risk of miscarriage: a prospective cohort study. Thyroid 201424 1642-1649. (https://doi.org/10.1089/thy.2014.0029)

60 Korevaar TI, Steegers EA, Pop VJ, Broeren MA, Chaker L, de Rijke YB, Jaddoe VW, Medici M, Visser TJ, Tiemeier H et al. Thyroid autoimmunity impairs the thyroidal response to human chorionic gonadotropin: two population-based prospective cohort studies. Journal of Clinical Endocrinology and Metabolism 2017102 69-77. (https://doi.org/10.1210/jc.2016-2942)

61 Vissenberg R, van den Boogaard E, van Wely M, van der Post JA, Fliers E, Bisschop PH \& Goddijn M. Treatment of thyroid disorders before conception and in early pregnancy: a systematic review. Human Reproduction Update 201218 360-373. (https://doi. org/10.1093/humupd/dms007)

62 Abalovich M, Gutiérrez S, Alcaraz G, Maccallini G, \& García A \& Levalle O. Overt and subclinical hypothyroidism complicating pregnancy. Thyroid 200212 63-68. (https://doi. org/10.1089/105072502753451986)

63 Lepoutre T, Debiève F, Gruson D \& Daumerie C. Reduction of miscarriages through universal screening and treatment of thyroid autoimmune diseases. Gynecologic and Obstetric Investigation 201274 265-273. (https://doi.org/10.1159/000343759)

64 Rotondi M, Mazziotti G, Sorvillo F, Piscopo M, Cioffi M, Amato G \& Carella C. Effects of increased thyroxine dosage pre-conception on thyroid function during early pregnancy. European Journal of Endocrinology 2004151 695-700. (https://doi.org/10.1530/ eje.0.1510695)

65 Negro R, Formoso G, Mangieri T, Pezzarossa A, Dazzi D \& Hassan H. Levothyroxine treatment in euthyroid pregnant women with autoimmune thyroid disease: effects on obstetrical complications. Journal of Clinical Endocrinology and Metabolism $2006912587-2591$. (https://doi.org/10.1210/jc.2005-1603)

66 Negro R, Greco G, Mangieri T, Pezzarossa A, Dazzi D \& Hassan H. The influence of selenium supplementation on postpartum thyroid status in pregnant women with thyroid peroxidase autoantibodies. Journal of Clinical Endocrinology and Metabolism 200792 1263-1268. (https:// doi.org/10.1210/jc.2006-1821)

67 Yassa L, Marqusee E, Fawcett R \& Alexander EK. Thyroid hormone early adjustment in pregnancy (the THERAPY) trial. Journal of Clinical Endocrinology and Metabolism 201095 3234-3241. (https://doi. org/10.1210/jc.2010-0013)

68 Negro R, Mangieri T, Coppola L, Presicce G, Casavola EC, Gismondi R, Locorotondo G, Caroli P, Pezzarossa A, Dazzi D et al. Levothyroxine treatment in thyroid peroxidase antibody-positive women undergoing assisted reproduction technologies: a prospective study. Human Reproduction 200520 1529-1533. (https://doi. org/10.1093/humrep/deh843)

69 Abdel Rahman AH, Aly Abbassy H \& Abbassy AA. Improved in vitro fertilization outcomes after treatment of subclinical hypothyroidism in infertile women. Endocrine Practices 201016 792-797. (https://doi. org/10.4158/EP09365.OR)

70 Kim CH, Ahn JW, Kang SP, Kim SH, Chae HD \& Kang BM. Effect of levothyroxine treatment on in vitro fertilization and pregnancy outcome in infertile women with subclinical hypothyroidism undergoing in vitro fertilization/intracytoplasmic sperm injection. Fertility and Sterility 201195 1650-1654. (https://doi.org/10.1016/j. fertnstert.2010.12.004)

71 Bernardi LA, Cohen RN \& Stephenson MD. Impact of subclinical hypothyroidism in women with recurrent early pregnancy loss. Fertility and Sterility 2013100 1326-1331. (https://doi.org/10.1016/j. fertnstert.2013.07.1975)

72 Bartáková J, Potluková E, Rogalewicz V, Fait T, Schöndorfová D, Telička Z, Krátký J \& Jiskra J. Screening for autoimmune thyroid disorders after spontaneous abortion is cost-saving and it improves the subsequent pregnancy rate. BMC Pregnancy and Childbirth 2013 13 217. (https://doi.org/10.1186/1471-2393-13-217)

73 Lata K, Dutta P, Sridhar S, Rohilla M, Srinivasan A, Prashad GR, Shah VN \& Bhansali A. Thyroid autoimmunity and obstetric outcomes in women with recurrent miscarriage: a case-control study. Endocrine Connections 20132 118-124. (https://doi.org/10.1530/ EC-13-0012)

74 Maraka S, Singh Ospina NM, O'Keeffe DT, Rodriguez-Gutierrez R, Espinosa De Ycaza AE, Wi CI, Juhn YJ, Coddington CC 3rd, Montori VM \& Stan MN. Effects of levothyroxine therapy on pregnancy outcomes in women with subclinical hypothyroidism. Thyroid 201626 980-986. (https://doi.org/10.1089/thy.2016.0014)

75 Negro R, Schwartz A \& Stagnaro-Green A. Impact of levothyroxine in miscarriage and preterm delivery rates in first trimester thyroid antibody-positive women with TSH less than $2.5 \mathrm{mIU} / \mathrm{L}$. Journal of Clinical Endocrinology and Metabolism 2016101 3685-3690. (https:// doi.org/10.1210/jc.2016-1803)

76 Nazarpour S, Ramezani Tehrani F, Simbar M, Tohidi M, Alavi Majd H \& Azizi F. Effects of levothyroxine treatment on pregnancy outcomes in pregnant women with autoimmune thyroid disease. European Journal of Endocrinology 2017176 253-265. (https://doi.org/10.1530/EJE-16-0548) 
77 Van den Berg MM, Vissenberg R \& Goddijn M. Recurrent miscarriage clinics. Obstetrics and Gynecology Clinics of North America 201441 145-155. (https://doi.org/10.1016/j.ogc.2013.10.010)

78 Harrison MS \& Goldenberg RL. Global burden of prematurity. Seminars in Fetal and Neonatal Medicine 201621 74-79. (https://doi. org/10.1016/j.siny.2015.12.007)

79 Korevaar TI \& Peeters RP. The potential benefit of levothyroxine treatment during pregnancy: another step forward. European Journal of Endocrinology 2017176 C3-C5. (https://doi.org/10.1530/ EJE-16-1058)

80 Hennessey JV, Garber JR, Woeber KA, Cobin R, Klein I \& AACE Thyroid Scientific Committee \& American College of Endocrinology (ACE). American Association of Clinical Endocrinologists and American College of Endocrinology Position Statement on Thyroid dysfunction case finding. Endocrine Practices 201622 262-270. (https://doi.org/10.4158/EP151038.PS)

81 Taylor PN, Minassian C, Rehman A, Iqbal A, Draman MS, Hamilton W, Dunlop D, Robinson A, Vaidya B, Lazarus JH et al. TSH levels and risk of miscarriage in women on long-term levothyroxine: a community-based study. Journal of Clinical Endocrinology and Metabolism 201499 3895-3902. (https://doi. org/10.1210/jc.2014-1954)

82 Lassi Z, Imam A, Dean S \& Bhutta Z. Preconception care: screening and management of chronic disease and promoting psychological health. Reproductive Health 201411 (Supplement 3) S5. (https://doi. org/10.1186/1742-4755-11-S3-S5)

83 Juch H, Lupattelli A, Ystrom E, Verheyen S \& Nordeng H. Medication adherence among pregnant women with hypothyroidism-missed opportunities to improve reproductive health? A cross-sectional, web-based study. Patient Education and Counseling 201699 1699-1707. (https://doi.org/10.1016/j.pec.2016.04.006)

84 Laurberg P, Andersen SL, Pedersen IB, Andersen S \& Carlé A. Screening for overt thyroid disease in early pregnancy may be preferable to searching for small aberrations in thyroid function tests. Clinical Endocrinology 201379 297-304. (https://doi.org/10.1111/cen.12232)
85 Behrooz HG, Tohidi M, Mehrabi Y, Behrooz EG, Tehranidoost M \& Azizi F. Subclinical hypothyroidism in pregnancy: intellectual development of offspring. Thyroid 201121 1143-1147. (https://doi. org/10.1089/thy.2011.0053)

86 Reh A, Grifo J \& Danoff A. What is a normal thyroid-stimulating hormone (TSH) level? Effects of stricter TSH thresholds on pregnancy outcomes after in vitro fertilization. Fertility and Sterility 201094 2920-2922. (https://doi.org/10.1016/j.fertnstert.2010.06.041)

87 Karmon AE, Batsis M, Chavarro JE \& Souter I. Preconceptional thyroid-stimulating hormone levels and outcomes of intrauterine insemination among euthyroid infertile women. Fertility and Sterility 2015103 258.e1-263.e1. (https://doi.org/10.1016/j. fertnstert.2014.09.035)

88 Rodriguez-Gutierrez R, Maraka S, Ospina NS, Montori VM \& Brito JP. Levothyroxine overuse: time for an about face? Lancet Diabetes and Endocrinology 20175 246-248. (https://doi.org/10.1016/S22138587(16)30276-5)

89 Wiles KS, Jarvis S \& Nelson-Piercy C. Are we overtreating subclinical hypothyroidism in pregnancy? BMJ 201512 h4726. (https://doi. org/10.1136/bmj.h4726)

90 Brabant G, Peeters RP, Chan SY, Bernal J, Bouchard P, Salvatore D, Boelaert K \& Laurberg P. Management of subclinical hypothyroidism in pregnancy: are we too simplistic? European Journal of Endocrinology 2015173 P1-P11. (https://doi.org/10.1530/EJE-14-1005)

91 Spremovic-Radjenovic S, Gudovic A, Lazovic G, Marinkovic J, Radunovic N \& Ljubic A. Fetal free thyroxine concentrations in pregnant women with autoimmune thyroid disease. Journal of Clinical Endocrinology and Metabolism 201297 4014-4021. (https:// doi.org/10.1210/jc.2012-1392)

92 Medici M, Timmermans S, Visser W, de Muinck Keizer-Schrama SM, Jaddoe VW, Hofman A, Hooijkaas H, de Rijke YB, Tiemeier H, Bongers-Schokking JJ et al. Maternal thyroid hormone parameters during early pregnancy and birth weight: the Generation R Study. Journal of Clinical Endocrinology and Metabolism 201398 59-66. (https://doi.org/10.1210/jc.2012-2420)

Received 18 July 2017

Revised version received 13 October 2017

Accepted 25 October 2017 